\title{
Selinexor, a Selective Inhibitor of Nuclear Export (SINE) compound, acts through NF-KB deactivation and combines with proteasome inhibitors to synergistically induce tumor cell death
}

\author{
Trinayan Kashyap ${ }^{1}$, Christian Argueta ${ }^{1}$, Amro Aboukameel ${ }^{2}$, Thaddeus John \\ Unger $^{1}$, Boris Klebanov ${ }^{1}$, Ramzi M. Mohammad ${ }^{2}$, Irfana Muqbil ${ }^{2}$, Asfar S. Azmi², \\ Claire Drolen ${ }^{1}$, William Senapedis ${ }^{1}$, Margaret Lee ${ }^{1}$, Michael Kauffman ${ }^{1}$, Sharon \\ Shacham ${ }^{1}$, Yosef Landesman ${ }^{1}$ \\ ${ }^{1}$ Karyopharm Therapeutics Inc., Newton, MA, 02459, USA \\ ${ }^{2}$ Department of Oncology, Wayne State University School of Medicine, Detroit, MI 48201, USA \\ Correspondence to: Trinayan Kashyap, email: tkashyap@karyopharm.com \\ Keywords: SINE, selinexor, XPO 1, NF-KB, proteasome inhibitors
}

Received: July 25, $2016 \quad$ Accepted: September 22, 2016

Published: October 04, 2016

\section{ABSTRACT}

The nuclear export protein, exportin-1 (XPO1/CRM1), is overexpressed in many cancers and correlates with poor prognosis. Selinexor, a first-in-class Selective Inhibitor of Nuclear Export (SINE) compound, binds covalently to XPO1 and blocks its function. Treatment of cancer cells with selinexor results in nuclear retention of major tumor suppressor proteins and cell cycle regulators, leading to growth arrest and apoptosis. Recently, we described the selection of SINE compound resistant cells and reported elevated expression of inflammation-related genes in these cells. Here, we demonstrated that NF-KB transcriptional activity is up-regulated in cells that are naturally resistant or have acquired resistance to SINE compounds. Resistance to SINE compounds was created by knockdown of the cellular NF-KB inhibitor, IKB-a. Combination treatment of selinexor with proteasome inhibitors decreased NF-KB activity, sensitized SINE compound resistant cells and showed synergistic cytotoxicity in vitro and in vivo. Furthermore, we showed that selinexor inhibited NF-kB activity by blocking phosphorylation of the IKB-a and the NF-KB p65 subunits, protecting IKB-a from proteasome degradation and trapping IKB-a in the nucleus to suppress NF-KB activity. Therefore, combination treatment of selinexor with a proteasome inhibitor may be beneficial to patients with resistance to either single-agent.

\section{INTRODUCTION}

Karyopherins, classified as importins and exportins, are a family of transport proteins that shuttle large $(>40 \mathrm{kDa})$ macromolecules between the nucleus and the cytoplasm [1, 2]. Exportin 1 (XPO1), also known as chromosomal region maintenance 1 (CRM1), is one of seven nuclear export proteins that mediate the transport of proteins, mRNA, rRNA, and snRNA out of the nucleus through the nuclear pore complex (NPC). XPO1 is the sole exporter of over 200 known cargos bearing leucine-rich nuclear export sequences (NES) [3], including major tumor suppressor proteins (TSPs) [4] such as p53, p73, p21, p27, pRb, FOXOs, BRCA1/2 and IкB- $\alpha$ (NFkBIA) ("NES on-line database" http://prodata.swmed.edu/LRNes/IndexFiles/names.php? sortby=nesID\&orederby=DESc:[5]), as well as other cell cycle regulators known to play substantial roles in cell proliferation and tumorigenesis, including survivin, NF- $\mathrm{\kappa B}$ [5] and eIF4E [6]. Increased XPO1 expression is observed in many hematological and solid tumor malignancies and is correlated with poor prognosis [7-10]. Overexpression of XPO1 increases the export of TSPs to the cytoplasm, preventing them from conducting their normal cell-cycle checkpoint regulation in the nucleus $[4,11]$.

Using structure-based drug design, we developed highly selective small molecule inhibitors of XPO1, also known as Selective Inhibitor of Nuclear Export (SINE) compounds, which covalently bind to cysteine 528 (Cys-528) of human XPO1, located within the NES cargo binding pocket $[12,13]$. XPO1 inhibition locks cargo proteins, including TSPs, in the nucleus leading to selective apoptosis of cancer cells, whereas, normal cells 
undergo transient cell cycle arrest [14-29]. Selinexor (KPT-330) is a first-in-class orally bioavailable SINE compound that is currently being evaluated in multiple late stage clinical trials in patients with relapsed and/or refractory hematological and solid tumor malignancies [30-32].

IкB- $\alpha$ (nuclear factor of kappa light polypeptide gene enhancer in B-cells inhibitor, alpha), a cargo of XPO1, inhibits the NF- $\kappa \mathrm{B}$ transcription factor by sequestering it in an inactive state in the cytoplasm, thus preventing NF$\kappa \mathrm{B}$ from entering the nucleus and binding DNA [33-35]. One consequence of XPO1 overexpression in cancer cells is excessive nuclear export of I $\mathrm{B}-\alpha$ to the cytoplasm where it is inactivated by proteasome-mediated degradation [36]. The resulting up-regulation of $\mathrm{NF}-\kappa \mathrm{B}$ transcriptional activity promotes inflammation and tumorigenesis. NF$\kappa \mathrm{B}$ is activated by various intra and extra cellular stimuli including cytokines, such as TNF $\alpha$ [36-39]. TNF $\alpha$ levels in the plasma of cancer patients positively correlate with tumor growth and increased metastasis in various malignancies [40-43]. TNF $\alpha$ binds to the TNF-receptor and initiates signaling cascades through the IкB kinase (IKK) complex [44]. The IKK complex is composed of 3 major subunits; IKK- $\alpha$ (IKK1), IKK- $\beta$ (IKK2) and IKK- $\gamma$ (NEMO) [45]. The $\alpha$ - and $\beta$-subunits form the catalytically active kinase domain, whereas the $\gamma$-subunit serves a regulatory function. Activated IKK phosphorylates I $\kappa$ B- $\alpha$ leading to its dissociation from NF- $\mathrm{KB}$ and proteasomemediated degradation [36, 46, 47]. Following release from $\mathrm{I} \kappa \mathrm{B}-\alpha$, the $\mathrm{NF}-\kappa \mathrm{B}$ complex (p65 and p50 subunits heterodimer) translocates into the nucleus and binds specific DNA sequences in the promoter region of target genes [39].

We have previously shown that selinexor inhibits $\mathrm{NF}-\kappa \mathrm{B}$ transcriptional activity even in the presence of $\mathrm{TNF} \alpha$ [48]. In order to fully understand the mechanisms underlying selinexor induced $\mathrm{NF}-\kappa \mathrm{B}$ inhibition, we investigated the role of $I \kappa \mathrm{B}-\alpha$ in cancer cell response to selinexor. Our data shows that silencing $\mathrm{I} \kappa \mathrm{B}-\alpha$ reduces the sensitivity to selinexor. We also show that NF- $\kappa \mathrm{B}$ transcriptional activity is elevated in cancer cells that are naturally resistant or have acquired resistance to selinexor. Finally, we demonstrate that resistance to selinexor can be overcome by combining selinexor with proteasome inhibitors. The combination of selinexor and proteasome inhibitors excerts synergistic cytotoxicity in vitro and in vivo suggesting a promising clinical combination strategy against selinexor resistant cancers.

\section{RESULTS}

\section{SINE compound resistance correlates with increased basal NF- $\mathrm{KB}$ activity}

We have previously described a SINE compound resistant HT-1080-R (fibrosarcoma) cell line (selinexor $\left.\mathrm{IC}_{50}: 2 \mu \mathrm{M}\right)$ that was generated in vitro by continuous exposure of the parental cell line (HT-1080, $\mathrm{IC}_{50}: 100$ $\mathrm{nM}$ ) to increasing concentrations of the SINE compound, KPT-185 [49]. Comparison of gene expression profiling between HT1080-R and parental HT-1080 cells revealed an increase of NF- $\mathrm{KB}$ pathway related genes in HT1080-R cells [49]. Both cell lines showed similar levels of baseline IкB- $\alpha$ expression and predominantly cytoplasmic localization, however following selinexor treatment, HT1080-R cells showed substantially less nuclear retention of I $\mathrm{B}-\alpha$ (Figure 1A-1D and [49]) compared to the parental HT-1080. To understand the role of NF- $\mathrm{kB}$ transcriptional activity in the context of selinexor sensitivity, we compared the basal levels of NF- $\mathrm{BB}$ DNA binding activity in the two cell lines. Consistent with our previous observation of increased NF- $\mathrm{kB}$ pathway gene expression in HT1080-R cells [49], we found $\sim 4$-fold increase in the NF- $\kappa B$ DNA binding activity in HT-1080-R compared to HT-1080 (Figure 1E). We then analyzed the NF-кB DNA binding activity in a naturally occurring SINE compound resistant alveolar soft part sarcoma cell line [50], ASPS$\mathrm{KY}\left(\mathrm{IC}_{50}:>10 \mu \mathrm{M}\right)$. We found that ASPS-KY cells had increased basal NF- $\mathrm{KB}$ DNA binding activity when compared to parental HT-1080 (6.5-fold) and HT-1080-R (1.7 fold), demonstrating a direct correlation between higher NF-kB activity and resistance to SINE compounds.

\section{IкB- $\alpha$ silencing decreases selinexor efficacy}

IкB- $\alpha$ inhibits NF- $\kappa \mathrm{B}$ complex (p65 and p50 subunits heterodimer) nuclear translocation, DNA binding and transactivation of target genes [39]. Therefore, we hypothesized that cancer cell resistance to SINE compoundinduced apoptosis may also correlate with lower expression

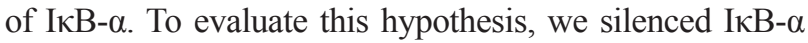
expression in the osteosarcoma U-2 OS cell line by using siRNA and measured the cytotoxic effects of selinexor

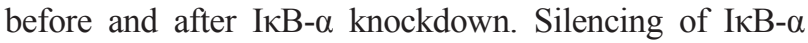
with siRNA for 96 hours resulted in a $90 \%$ reduction of I $\mathrm{B}-\alpha$ protein expression (Figure $2 \mathrm{~A}$ ) and a subsequent 65 -fold decrease in the cytotoxicity of selinexor (Figure 2B and Table 1). Conversely, cells transfected with control siRNA showed no change in their sensitivity to selinexor compared to the parental cell line. These results demonstrate that decreases in IкB- $\alpha$ protein expression contribute to the selinexor resistance in cancer cells.

\section{Combination with proteasome inhibitors overcomes selinexor resistance}

Proteasome inhibitors such as bortezomib and carfilzomib protect IкB- $\alpha$ from degradation, thereby inhibiting nuclear translocation and activation of NF- $\mathrm{KB}$ $[51,52]$. Having demonstrated that cellular resistance to selinexor is correlated with increased NF- $\mathrm{KB}$ transactivation and decreased I $\kappa \mathrm{B}-\alpha$ protein expression, we sought to determine if proteasome inhibitors could 
overcome resistance to selinexor by preventing I $\mathrm{B}-\alpha$ degradation. Therefore, HT-1080-R cells were treated with $1 \mu \mathrm{M}$ selinexor, $100 \mathrm{nM}$ bortezomib, or a combination of both compounds for 6 hours. The cells were then fixed and stained with an I $\kappa \mathrm{B}-\alpha$ antibody and examined for sub-cellular localization. While bortezomib alone did not alter the predominantly cytoplasmic localization of I $\mathrm{B}-\alpha$, the proteasome inhibitor enhanced selinexor- induced nuclear localization of I $\mathrm{KB}-\alpha$ in HT-1080-R cells (Figure 3A). In addition, the combination treatment resulted in more inhibition of the DNA binding activity of the NF- $\mathrm{BB}(56 \%)$ compared with either drug alone (selinexor 20\% and bortezomib 40\%) (Figure 3B). Nuclear-cytoplasmic fractionation of HT-1080-R cells treated with selinexor, bortezomib or the combination confirmed the enhanced nuclear localization of $\mathrm{I} \kappa \mathrm{B}-\alpha$ with
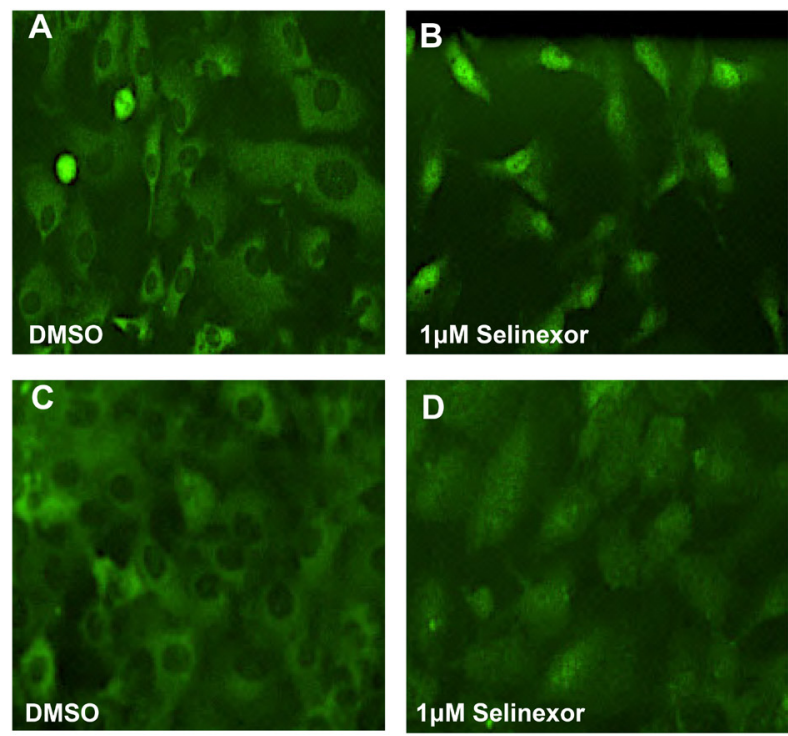

E

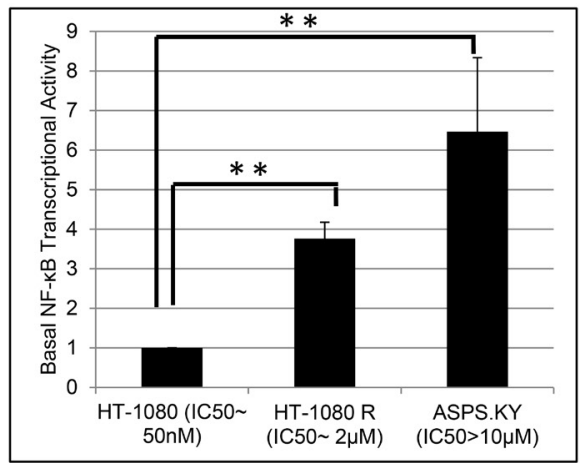

Figure 1: SINE compound resistant cell lines showed increased basal levels of NF- $\mathrm{B}$ transcriptional activity. SINE compound resistant HT-1080 (fibrosarcoma, HT-1080-R) cells were selected by continued exposure of sensitive parental cells in increasing concentrations of the SINE compound KPT-185. A, B. Parental and C, D. HT-1080-R cells were treated with $1 \mu \mathrm{M}$ of selinexor for 4 hours. SINE compound-induced nuclear retention of IкB- $\alpha$ was evaluated by immunofluorescence microscopy and shown to be impaired in SINE compound resistant cells. E. Parental-sensitive HT-1080, HT-1080-R, and ASPS-KY (Alveolar Soft Part Sarcoma) cells were tested for NF- $\mathrm{KB}$ transcriptional activity by ELISA assay. Equal number of cells from the 3 cell lines were lysed with RIPA buffer. The results from 2 independent assays show that higher NF- $\mathrm{kB}$ transcriptional activity is correlated with lower sensitivity to the cytotoxic effects of selinexor. The error bars indicate the standard deviation and the Student's t-test was used to calculate $\mathrm{p}$ values. ${ }^{* *} \mathrm{p}<0.01$.

A

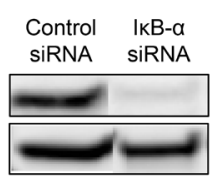

IKB- $\alpha$

$\beta$-Actin

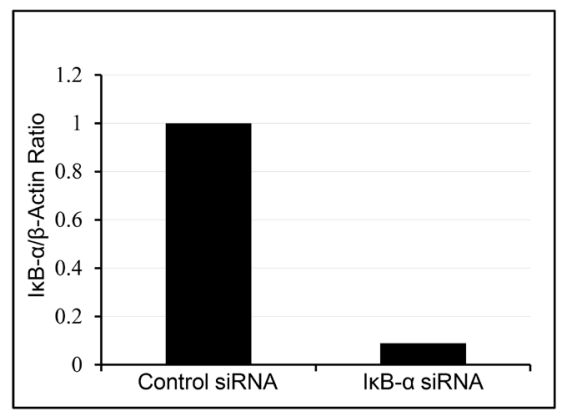

B

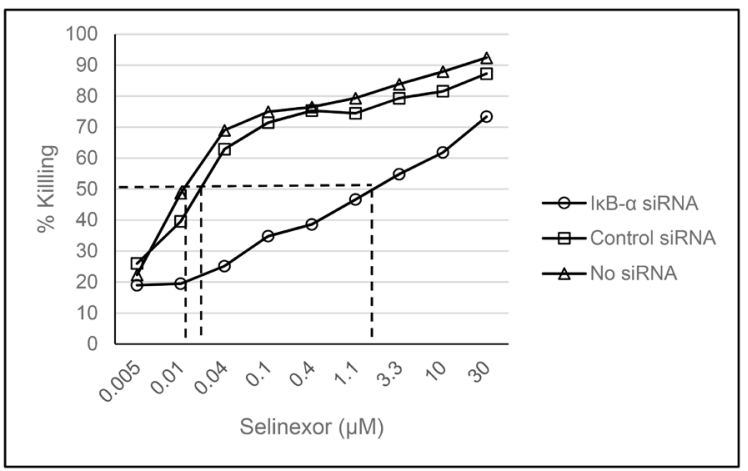

Figure 2: Reduction in the levels of IKB- $\alpha$ affects the potency of selinexor. A. U-2 OS cells were transfected with either 40nM I $\mathrm{B}-\alpha$ or control siRNA using lipofectamine RNAiMax. At 96 hours post transfection there was a $90 \%$ reduction in the protein levels of I $\mathrm{B}-\alpha$. B. The siRNA transfected and non-transfected U-2 OS cells were treated with increasing concentrations of selinexor and cells were assayed for the cytotoxic effect of selinexor 72 hours post treatment. 
Table 1: IкB- $\alpha$ knockdown in U-2 OS cells reduced selinexor cytotoxicity by 65-fold, whereas control siRNA showed no effects on selinexor potency

\begin{tabular}{lcc}
\hline & Selinexor IC $_{\mathbf{5 0}}(\boldsymbol{\mu M})$ & Fold Change \\
\hline No transfection & 0.027 & 1 \\
Control siRNA & 0.023 & 0.85 \\
I $\mathrm{B}-\alpha$ siRNA & 1.85 & 65.5 \\
\hline
\end{tabular}

the combination (Figure $3 \mathrm{C}$ ). In addition to I $\kappa \mathrm{B}-\alpha$, the combination also enhanced the nuclear accumulation of the tumor suppressor proteins p53, p21 and Foxo3A as compared to either selinexor or bortezomib treatment alone (Figure 3C). The enhancement of selinexor induced XPO1 inhibition by bortezomib prompted us to test the cytotoxic efficacy of the combination. Treatment of HT-1080-R and ASPS-KY cells with $1 \mu \mathrm{M}$ selinexor or $50 \mathrm{nM}$ bortezomib alone induced low levels of apoptosis (HT-1080-R by bortezomib and ASPS-KY by both single agents), whereas the combination induced marked apoptosis as demonstrated by PARP and caspase 3 cleavage (Figure 3D). In the presence of carfilzomib at its $\mathrm{IC}_{25}(4 \mathrm{nM})$, the cytotoxic potency of SINE compound, KPT-185, was enhanced by 15-fold in HT-1080-R cells (Table 2). Similarly, bortezomib enhanced KPT-185 potency by 39 folds. Cellular sensitivity to selinexor was also enhanced by 12 -fold when combined with bortezomib in the selinexor- and bortezomib-resistant ASPS-KY cell line (Table 2).

\section{In vivo combination of the proteasome inhibitor, bortezomib with selinexor is more efficacious than either single agent in SINE compound resistant tumors}

In order to evaluate the activity of selinexor either as a single agent or in combination with bortezomib, a sub-cutaneous xenograft model of HT-1080-R cells was established in ICR-SCID mice. The tumor-bearing mice were treated with vehicle, bortezomib (1 $\mathrm{mg} / \mathrm{kg}$; IV), selinexor (15 mg/kg; PO) or the combination of bortezomib $(1 \mathrm{mg} / \mathrm{kg})$ and selinexor $(15 \mathrm{mg} / \mathrm{kg})$ twice a week for 2 weeks. The study was terminated once tumors in the vehicle treated mice group approached $1800 \mathrm{mg}$. While bortezomib treatment had little effect on tumor growth (15\% inhibition) in this model, selinexor treatment resulted in 50\% inhibition of tumor growth and the combination treatment resulted in $76 \%$ inhibition of tumor growth when compared to the vehicle treatment group at the end of the study (Figure 4). These results confirmed the in vitro finding that bortezomib treatment can sensitize SINE compound resistant tumor cells to selinexor treatment. These data suggest that combining selinexor with a proteasome inhibitor may be synergistic in cancer patients that have become selinexor or bortezomib (or other proteasome inhibitors e.g. carfilzomib or ixazomib) resistant.

\section{Selinexor inhibits NF-кB DNA binding and promotes nuclear localization of IкB- $\alpha$ and protection from degradation}

$\mathrm{NF}-\kappa \mathrm{B}$ is a transcriptional regulator activated by cytokines, such as TNF $\alpha$ [37]. Figure 5 shows a 10-fold induction of NF- $\mathrm{B}$ p 65 DNA binding activity upon exposure of the U-2 OS cells to TNFa. However, pretreatment of the cells with selinexor prior to the addition of $\mathrm{TNF} \alpha$ inhibits induction of $\mathrm{NF}-\kappa \mathrm{B}$ activity in a dose dependent manner with an $\mathrm{IC}_{50}$ of $6.72 \mu \mathrm{M}$. Similar results were seen in other solid [48] and hematological cell lines (data not shown).

In order to understand how selinexor inhibits NF$\kappa \mathrm{B}$ activation, we treated U-2 OS cells with increasing concentrations of selinexor in the presence or absence of the NF- $\kappa \mathrm{B}$ activator $\mathrm{TNF} \alpha$. Then cell lysates were analyzed by Western blotting for total and phosphorylated I $\kappa \mathrm{B}-\alpha$ and the NF- $\kappa \mathrm{B}$ p65 subunit protein levels. Treatment with TNF $\alpha$ alone induced the phosphorylation of IкB- $\alpha$ on serine $32 / 36$ and the phosphorylation of NF- $\mathrm{BB}$ p65 on serine 536. Phosphorylation of these sites has been reported by others to be mainly IKK-dependent leading to the proteasomal degradation of total $\mathrm{I} \kappa \mathrm{B}-\alpha$ and subsequently to the activation of NF- $\kappa \mathrm{B}$ (reviewed in [44]), (Figure 6A). Conversely, treatment of U-2 OS cells with selinexor following TNF $\alpha$ exposure abrogated TNF $\alpha$ induced NF$\kappa \mathrm{B}$ and $\mathrm{I} \kappa \mathrm{B}-\alpha$ phosphorylation, protecting I $\mathrm{KB}-\alpha$ from degradation and preventing the activation of the $N F-\kappa B$ complex (Figure 6A and see Figure 3B). To confirm that the inhibition of $\mathrm{I} \kappa \mathrm{B}-\alpha$ and NF- $\mathrm{NB}$ p 65 phosphorylation by selinexor was not due to direct disruption of IKK kinase activity, increasing concentrations of selinexor were evaluated in an IKK $\beta$ kinase immunoassay using a recombinant I $\kappa \mathrm{B}-\alpha$ peptide substrate containing the target site of IKK $\beta$ phosphorylation (serine 32/36 residues). These results show that selinexor, even at concentrations as high as of $100 \mu \mathrm{M}$, did not directly inhibit IKK $\beta$ kinase activity (Figure 6B).

In addition to preventing I $\mathrm{B}-\alpha$ degradation, selinexor induces nuclear accumulation of I $\mathrm{KB}-\alpha$ in the presence of TNF $\alpha$ (Figure 6C). This nuclear retention in the presence of $\mathrm{TNF} \alpha$ was also confirmed by cell fractionation studies (Figure $6 \mathrm{C}$ ). In addition to I $\kappa \mathrm{B}-\alpha$, selinexor also induced the nuclear accumulation of NF- $\kappa B$ p65 subunit, a cargo of XPO1 (Figure 6D). Interestingly, 
A
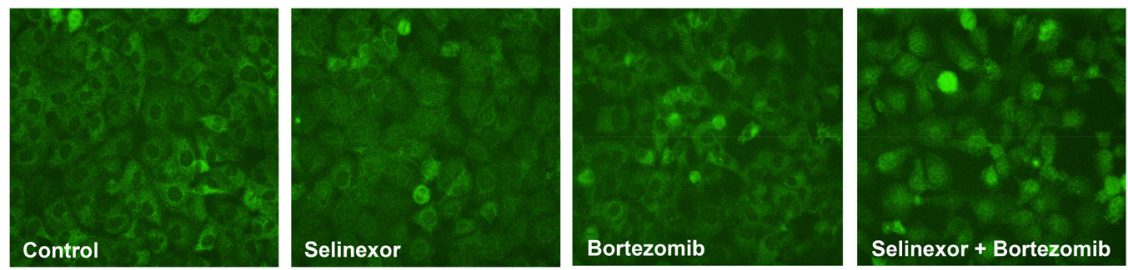

B

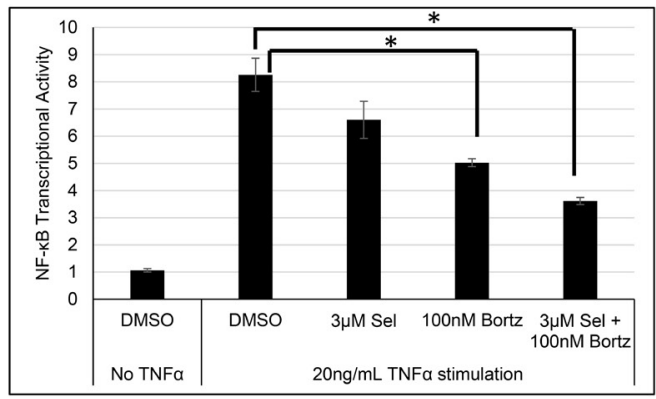

C

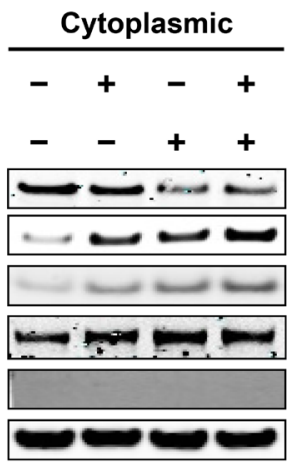

$1 \mu \mathrm{M}$ Selinexor

100nM Bortezomib

IKB- $\alpha$

p53

p21

Foxo3A

Lamin B

GAPDH

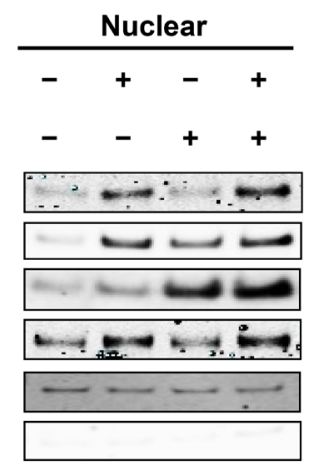

D

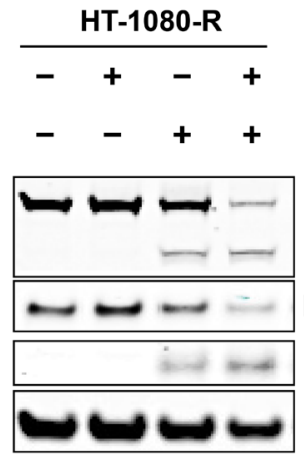

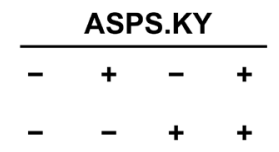

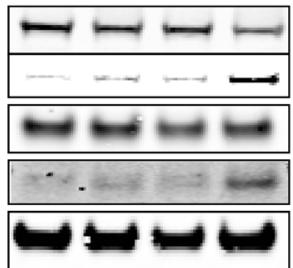

Figure 3: Combination with proteasome inhibitors overcomes selinexor resistance in cell lines. A. HT-1080-R cells were treated with $1 \mu \mathrm{M}$ of selinexor and/or $100 \mathrm{nM}$ bortezomib for 12 hours. The cells were fixed and the cellular localization of IkB- $\alpha$ was evaluated by immunofluorescence microscopy. Selinexor treatment showed minimal nuclear entrapment of IkB- $\alpha$, but combined treatment with selinexor and bortezomib further increased nuclear retention of IкB- $\alpha$. B. HT-1080-R cells were pre-treated with $3 \mu \mathrm{M}$ of selinexor (Sel) and/or 100nM bortezomib (Bortz) for 2 hours and then exposed to $20 \mathrm{ng} / \mathrm{mL}$ TNF $\alpha$ for 4 hours in serum free media followed by evaluation for DNA binding activity. TNF $\alpha$ treatment induced NF- $\mathrm{BB}$ transcriptional activity by 8 -fold, whereas treatment with the combination of selinexor and bortezomib reduced the activity by $60 \%$ compared to $20 \%$ and $40 \%$ by the single agent respectively. The error bars indicate standard deviation and the Student's t-test was used to calculate $p$ values. ${ }^{*} p<0.05$. C. Sub-cellular localization of XPO1 cargos in HT$1080-\mathrm{R}$ cells treated with $1 \mu \mathrm{M}$ of selinexor and/or $100 \mathrm{nM}$ bortezomib for 12 hours was evaluated by cellular fractionation and Western blotting. The combination treatment of selinexor and bortezomib increased nuclear levels of XPO1 cargos compared to either single agent treatment. Lamin B served as a nuclear protein marker; GAPDH as a cytosolic protein marker. D. HT-1080-R and ASPS-KY cells were treated with $1 \mu \mathrm{M}$ of selinexor and/or $50 \mathrm{nM}$ bortezomib for 24 hours. The combination of selinexor and bortezomib was more cytotoxic than either one of the single agents as indicated by pronounced cleavage of PARP and Caspase 3 with the combination. 
Table 2: HT-1080-R and ASPS-KY cells were treated for 72 hours with serial dilutions of the indicated SINE compounds with/without proteasome inhibitors at concentrations below their $\mathrm{IC}_{50}$

\begin{tabular}{lcc}
\hline & HT-1080-R & \\
\hline Compound & IC $_{\mathbf{5 0}}(\boldsymbol{\mu M})$ & Fold Change \\
\hline KPT-185 & 4.3 & $\mathbf{1}$ \\
Bortezomib & 0.0048 & $\mathbf{3 9}$ \\
KPT-185 + 4.1 nM Bortezomib & 0.11 & \\
Carfilzomib & 0.0076 & $\mathbf{1 5 . 4}$ \\
KPT-185 + 4.1 nM Carfilzomib & 0.28 & \\
\hline & ASPS-KY & Fold Change \\
\hline Compound & $\mathbf{I C}_{\mathbf{5 0}}(\boldsymbol{\mu M})$ & $\mathbf{1}$ \\
Selinexor & 22 & \\
Bortezomib & $>>1$ & $\mathbf{1 1 . 6 4}$ \\
Selinexor $+1 \mu \mathrm{M}$ Bortezomib & 1.89 & \\
\hline
\end{tabular}

Proteasome inhibitors sensitized HT-1080-R and ASPS-KY cells to SINE compounds by 39- and 12-fold respectively.

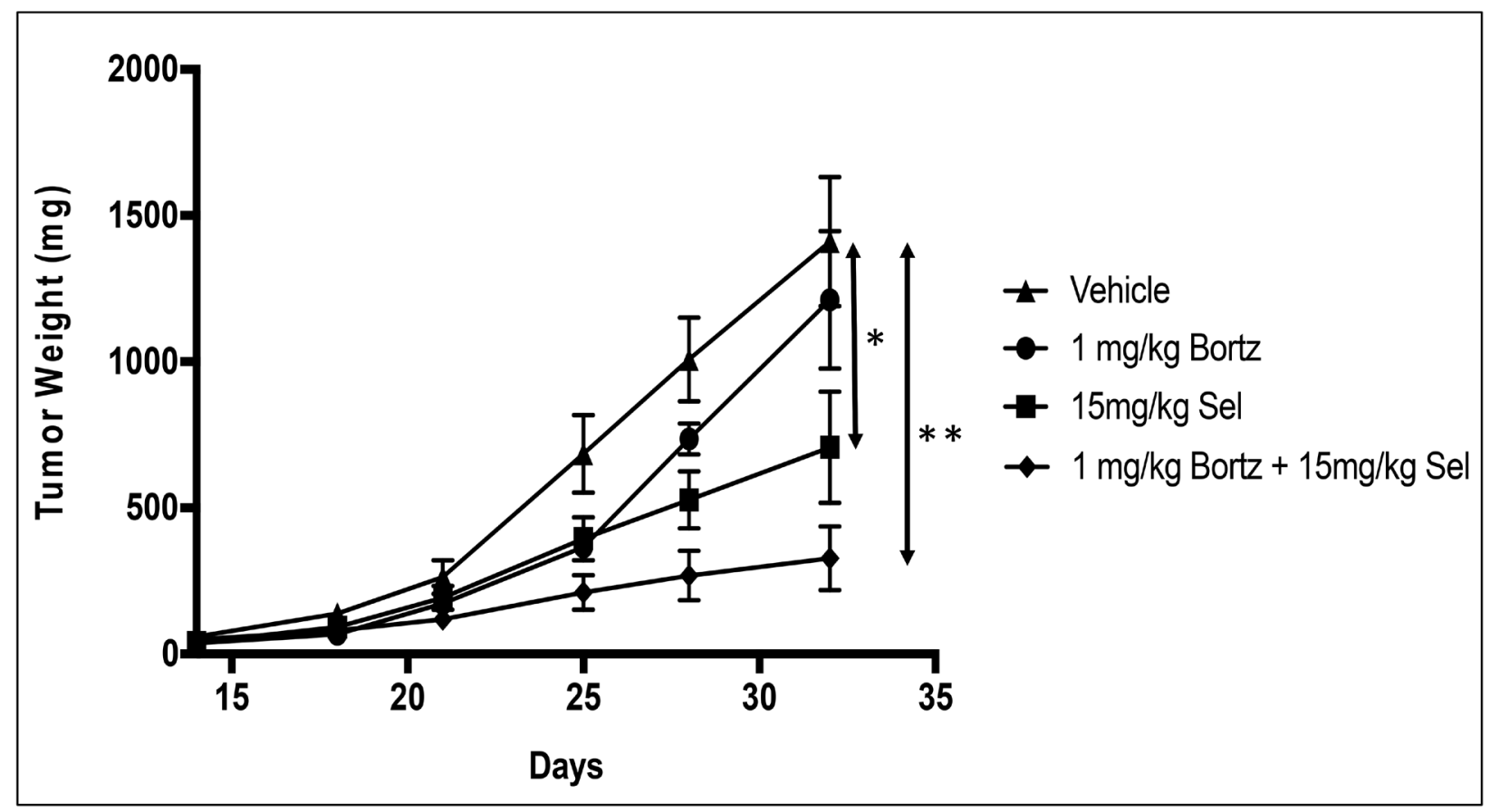

Figure 4: In vivo combination of bortezomib with selinexor is more efficacious than either single agent in the SINE compound resistant tumors. HT-1080-R cells $\left(1 \times 10^{6}\right)$ were subcutaneously injected in the flank of 3 naivve mice. Four weeks post injection, palpable tumors were formed at which time mice were euthanized, and tumors harvested and $50 \mathrm{mg}$ pieces were re-implanted unilaterally into the flank of experimental groups. Bortezomib (Bortz) at $1 \mathrm{mg} / \mathrm{kg}$ iv; selinexor (Sel) $15 \mathrm{mg} / \mathrm{kg}$ orally or the combination of bortezomib at $1 \mathrm{mg} / \mathrm{kg}+$ selinexor at $15 \mathrm{mg} / \mathrm{kg}$ was administered Monday and Thursday for 2 weeks. Effects on tumor weight were recorded as described in materials and methods. Data shown are the mean for each group. The bortezomib by itself showed no significant tumor reduction. Selinexor as single agent and in combination showed $50 \%$ and $76 \%$ tumor weight reduction respectively at the end of the study (day 32). The error bars indicate SEM and the Student's t-test was used to calculate $p$ values. ${ }^{*} \mathrm{p}<0.05,{ }^{* *} \mathrm{p}<0.01$. 
immunoprecipitation of I $\kappa \mathrm{B}-\alpha$ showed that I $\mathrm{I} \mathrm{B}-\alpha$ was bound to NF- $\kappa$ B p65 subunit both in the nucleus and cytoplasm (Figure $6 \mathrm{E}$ ) and that association of NF- $\kappa \mathrm{B}$ p65 with $I \kappa \mathrm{B}-\alpha$ in the nucleus is enhanced in the selinexor treated cells. This data suggests that although selinexor enhances nuclear localization of the NF- $\kappa B$ p 65 subunit, I $\kappa$ B- $\alpha$ nuclear localization is also enhanced, allowing I $\kappa$ B- $\alpha$ binding and inhibition of $\mathrm{NF}-\kappa \mathrm{B}$ activity in the nucleus, thus preventing $\mathrm{NF}-\kappa \mathrm{B}$ dependent gene transactivation.

\section{DISCUSSION}

XPO1 is a key member of the karyopherin family of nuclear transporters and a master regulator of NESdependent nuclear export. XPO1 overexpression is advantageous for oncogenesis and for the maintenance of the cancerous phenotype. The XPO1 mediated enhanced nuclear export of tumor suppressors leads to their exclusion from the nucleus, loss of cell cycle checkpoint regulation and therefore for aggressive uncontrolled cell growth and an anti-apoptotic phenotype [1]. Several natural and synthetic XPO1 inhibitors such as Leptomycin B, Anguinomycin A, Ratjadone A, and CBS9106 [53, 54] have been studied in vitro and in vivo. However, only selinexor has advanced to later stage clinical trials [30-32]. Selinexor covalently binds to Cys-528 in the cargo-binding pocket of human XPO1 [54] leading to trapping of XPO1 cargo proteins in the nucleus. This leads to the induction of apoptosis in cancer cells through re-activation of tumor suppressor function, while sparing normal cells [55]. In an effort to understand cancer cell resistance to SINE compounds, we established a SINE compound resistant cell line from the parental sensitive fibrosarcoma HT-1080 cell line [49]. The relatively long period of selection necessary to enrich for this resistant HT-1080 cell line ( $>9$ months) and the fact that no mutations were identified in the cargo binding pocket of XPO1 isolated from resistant cells is very encouraging from a clinical perspective. This suggests that the XPO1 drug target is relatively resistant to the development of active-site mutations as compared to kinase targets that tend to acquire mutations and become resistant to kinase inhibitors more quickly in vitro [56].

Two observations in the SINE compound resistant cells that we isolated indicated that NF- $\kappa \mathrm{B}$ activity is central for selinexor sensitivity. First, increased expression of inflammation-related genes is observed in the SINE compound resistant cell line HT1080-R as compared to the parental HT-1080 cells. Second, the ability of selinexor to induce nuclear localization of XPO1 cargos is reduced in SINE compound-resistant cells [49]. Of the several XPO1 cargos examined in the SINE compound-resistant cells, nuclear localization of I $\mathrm{B}-\alpha$ was most dramatically reduced. The role of $\mathrm{NF}-\kappa \mathrm{B} / \mathrm{I} \kappa \mathrm{B}-\alpha$ in selinexor sensitivity, was confirmed through measurements of high NF- $\kappa$ B activity in resistant cells and defining resistance of I $\mathrm{KB}-\alpha$ deficient cells to selinexor ( $\sim 65$-fold less potent). These results suggest that functional I $\kappa \mathrm{B}-\alpha$ is required for optimal selinexor efficacy. Functionally active I $\kappa \mathrm{B}-\alpha$ inhibits NF- $\kappa \mathrm{B}$ transcriptional activity by masking the nuclear localization signals (NLS) of NF- $\kappa \mathrm{B}$ proteins and sequestering the NF- $\kappa \mathrm{B}$ complex in the cytoplasm in an inactive form [34]. Our results further suggest that I $\kappa \mathrm{B}-\alpha$ can inhibit NF- $\kappa \mathrm{B}$ activity in the nuclear compartment as well.

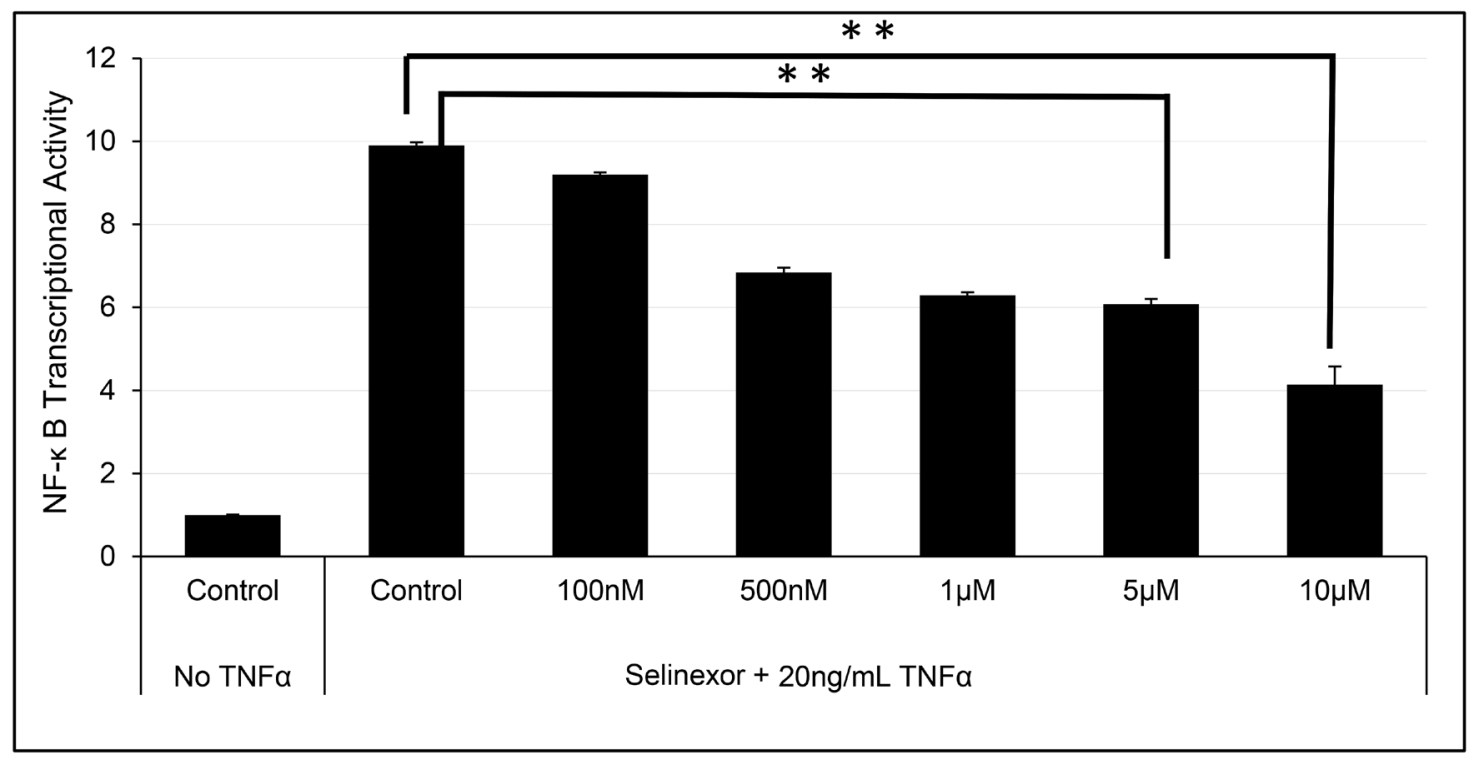

Figure 5: Selinexor inhibited NF-кB transcriptional activity. U-2 OS cells were pre-treated with different concentrations of selinexor for 2 hours and then exposed to TNF $\alpha$ for 4 hours in serum free media. TNF $\alpha$ exposure induced NF- $\kappa B$ transcriptional activity by 10 -fold. Selinexor inhibited NF-kB transcriptional activity in a dose dependent manner. The error bars indicate standard deviation and the Student's t-test was used to calculate $\mathrm{p}$ values. ${ }^{*} \mathrm{p}<0.01$. 
A

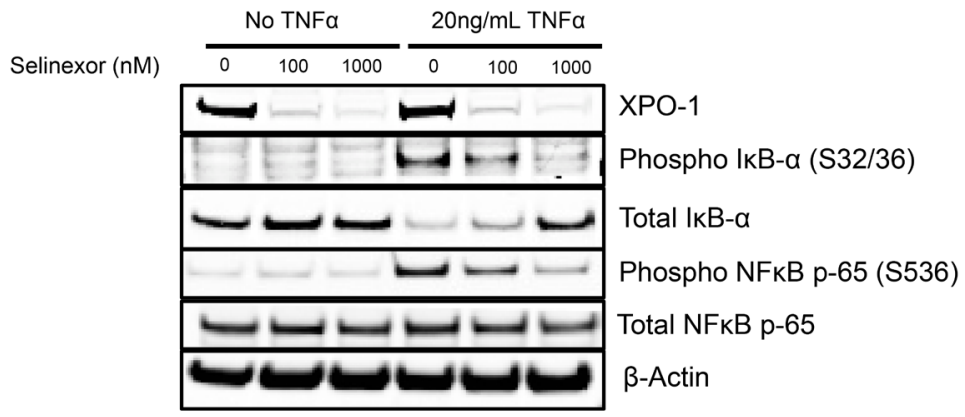

B

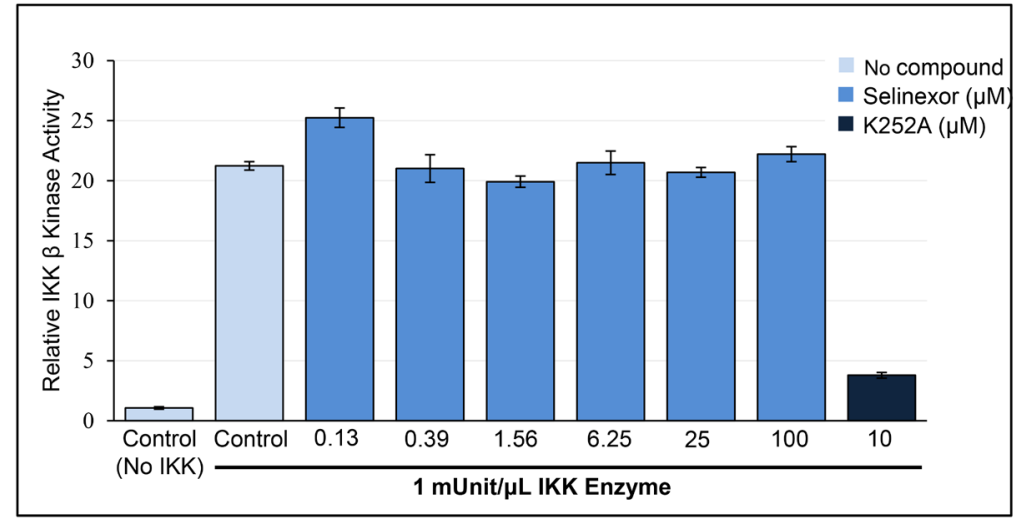

C

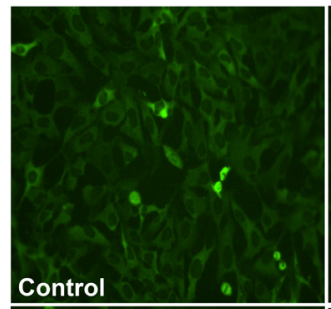

D
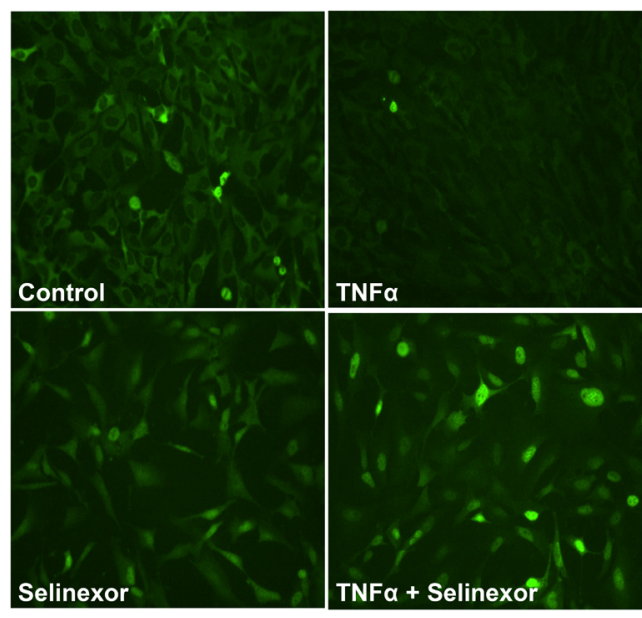

E
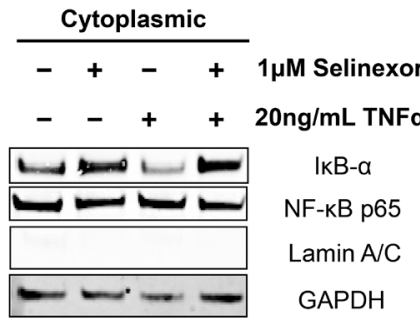

IкB- $\alpha$

NF-kB p65

Lamin A/C

GAPDH

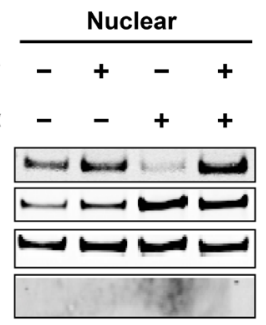

\begin{tabular}{|c|c|c|c|c|c|c|c|c|}
\hline \multicolumn{9}{|c|}{ IKB-a IP } \\
\hline \multicolumn{4}{|c|}{ Cytoplasmic } & \multirow[b]{2}{*}{$1 \mu \mathrm{M}$ Selinexor } & \multicolumn{4}{|c|}{ Nuclear } \\
\hline- & + & - & + & & - & + & - & + \\
\hline- & - & + & + & $20 \mathrm{ng} / \mathrm{mL}$ TNF $\alpha$ & - & - & + & + \\
\hline ter & 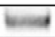 & sent & $=$ & IкB- $\alpha$ & $-\infty$ & nant & 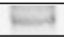 & $=$ \\
\hline 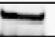 & $\Rightarrow$ & $\$ 4$ & $=$ & NF-кB p65 & ᄂ & 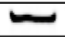 & $=$ & \\
\hline
\end{tabular}

Figure 6: Inhibition of NF-кB transcriptional activity by selinexor is associated with nuclear localization of IкB- $\alpha$ and protection from degradation. A. U-2 OS cells were stimulated with or without $20 \mathrm{ng} / \mathrm{mL}$ TNF $\alpha$ for 2 hours before being treated with vehicle, $100 \mathrm{nM}$ or $1 \mu \mathrm{M}$ selinexor for the next 24 hours. Western blot of phospho-IкB- $\alpha$ and phosphor-NF-kB p-65 shows that selinexor reverts the pro-inflammatory effects of TNF $\alpha$ and selinexor also increased cellular levels of IkB- $\alpha$. Selinexor induces XPO1 degradation. It is mediated by the proteasome degradation pathway (TK and YL, not shown). B. IKK $\beta$ kinase activity was analyzed by in vitro kinase assay using recombinant IKK $\beta$, recombinant IKB- $\alpha$ substrate containing serine 32/36 residues and selinexor at different concentrations. IKK $\beta$ kinase activity was detected using a phosphorylation specific IKB- $\alpha$ antibody. Selinexor had no inhibitory effects on IKK $\beta$ kinase activity. The pan-kinase inhibitor K252A was used as a positive control for the assay. C. Immunofluorescence staining of IкB- $\alpha$ after treatment with $20 \mathrm{ng} / \mathrm{mL}$ TNF $\alpha$ or $/$ and $1 \mu \mathrm{M}$ selinexor for 24 hours. Selinexor induced nuclear localization of IKB- $\alpha$ in the presence or absence of TNF $\alpha$. D. Cellular fractionation of U-2 OS cells shows similar increased nuclear levels of IкB- $\alpha$ and NF-kB p65 upon selinexor treatment even in the presence of TNF $\alpha$. Lamin A/C was used as nuclear protein marker; GAPDH as a cytosolic protein marker. E. IאB- $\alpha$ immunoprecipitation (IP) and Western blotting of cytoplasmic and nuclear fractions of U-2OS cells treated with selinexor and TNF $\alpha$ shows that IkB- $\alpha$ binds to NF-KB p65 subunit both in the nucleus and cytoplasm. 
Proteasome inhibitors such as bortezomib and carfilzomib are known to inhibit NF- $\kappa \mathrm{B}$ activity by preventing the degradation of I $\mathrm{KB}-\alpha$ [51]. Since upregulation of $\mathrm{NF}-\mathrm{\kappa B}$ activity contributes to selinexor resistance, we examined whether the combination of proteasome inhibitors with selinexor could overcome resistance to SINE compounds. Combination treatment of HT-1080-R and ASPS-KY cells with selinexor and bortezomib re-sensitized the cells to the cytotoxic effects of selinexor by 39- and 12-fold, respectively. Similar synergistic effects were observed when selinexor was combined with carfilzomib (Table 2). In vivo studies with HT-1080-R cells confirmed the enhanced activity of the combination observed in vitro. This synergy could be explained by the increased nuclear accumulation of IкB- $\alpha$ seen with the combination of proteasome and nuclear export inhibition. Therefore, the resulting increase in nuclear I $\kappa$ B- $\alpha$ following combination treatment translates to greater inhibition of $\mathrm{NF}-\kappa \mathrm{B}$ nuclear transcriptional activity with both XPO1 and proteasome inhibition, compared to either single mechanism alone.

Activation of the NF- $\mathrm{B}$ pathway induces cell division, uncontrolled cancer cell proliferation and inflammation. Cytokines, such as TNF $\alpha$, activate the NF$\kappa \mathrm{B}$ pathway by initiating phosphorylation and subsequent proteasomal degradation of $I \kappa B-\alpha$, which releases the $\mathrm{NF}-\kappa \mathrm{B}$ protein complex [39]. The NF- $\kappa \mathrm{B}$ complex then translocates into the nucleus and mediates the transcription of proteins involved in cell survival, proliferation and inflammation. TNF $\alpha$ has been previously reported to correlate with the extent of disease in cancer patients. Significant TNF $\alpha$ elevation in metastatic disease when compared to localized disease has been reported in breast, prostate, pancreatic and gastric cancer patients [40-43]. Selinexor inhibits the $\mathrm{TNF} \alpha$-induced transcriptional activity of $\mathrm{NF}-\kappa \mathrm{B}$. Our studies demonstrate that this is achieved through the inhibition of XPO1-mediated nuclear export of key members of the NF- $\kappa \mathrm{B}$ pathway, namely NF- $\kappa$ B p65 subunit and I $\kappa \mathrm{B}-\alpha$. Selinexor inhibits the nuclear export of both proteins, sequestering them in the cell nucleus and enabling NF- $\kappa \mathrm{B}$ inactivation through IкB- $\alpha$ binding.

It has been previously reported that the presence of $\mathrm{I} \kappa \mathrm{B}-\alpha$ in the nucleus prevents NF- $\kappa \mathrm{B}$ from binding to DNA sequences in the promoter of target genes [57, 58]. The accumulation of I $\mathrm{BB}-\alpha$ in the nucleus following exposure to selinexor could explain this inhibition of $\mathrm{NF}-\kappa \mathrm{B}$ transcriptional activity. Our immunoprecipitation

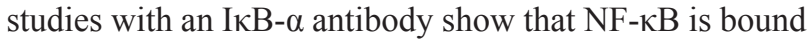
to I $\mathrm{B}-\alpha$ both in the nucleus and in the cytoplasm. In addition, selinexor treatment increases the amount of

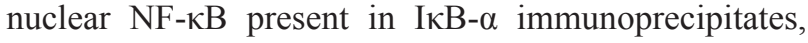
corresponding to an increase of the nuclear fraction of $\mathrm{NF}-\kappa \mathrm{B}$.

Importantly, inhibition of the $\mathrm{NF}-\kappa \mathrm{B}$ signaling by selinexor is not solely achieved through the forced nuclear accumulation of I $\kappa \mathrm{B}-\alpha$. Our data demonstrates that additional mechanisms lead to the inhibition of $\mathrm{TNF} \alpha$-induced degradation of I $\mathrm{KB}-\alpha$. Selinexor also induces inhibition of phosphorylation of $\mathrm{I} \kappa \mathrm{B}-\alpha$ and the NF- $\kappa$ B p65 subunit. These sites are known to be phosphorylated by IKK. Therefore, we speculate that selinexor indirectly inhibits IKK phosphorylation of both I $\mathrm{KB}-\alpha$ and $\mathrm{NF}-\kappa \mathrm{B}$ p65 subunit marking an additional way by which selinexor inhibits $N F-\kappa B$ activity (Figure 6A). TNF $\alpha$ mediated phosphorylation [44] is inhibited by selinexor in a dose dependent manner, protecting $\mathrm{I} \kappa \mathrm{B}-\alpha$ from degradation and preventing phosphorylation and activation of the NF$\kappa \mathrm{B}$ complex. The mechanism of selinexor blockade of $\mathrm{NF}-\kappa \mathrm{B}$-activating phosphorylation is currently a focus of active investigation in our lab.

In another report in this issue, Turner et al. examined the combination of selinexor with proteasome inhibitors in multiple myeloma cell lines and patient samples that are resistant to proteasome inhibitor treatment. The authors report that XPO1 inhibition as well as combination treatment of selinexor with bortezomib or carfilzomib sensitize the resistant cells to the cytotoxic effects of proteasome inhibitors. Together our studies highlight the $\mathrm{NF}-\kappa \mathrm{B}$ signaling as a critical pathway determining cancer cell response to selinexor and suggest a rationale for drug combination treatment to overcome drug resistance.

In conclusion, elevated $\mathrm{NF}-\kappa \mathrm{B}$ transcriptional activity may predict resistance to SINE compounds. Higher I $\kappa \mathrm{B}-\alpha$ protein expression and low NF- $\kappa \mathrm{B}$ transcriptional activity are associated with SINE compound sensitivity in tumor cells. Selinexor treatment blocks the degradation of I $\mathrm{KB}-\alpha$, induces its nuclear localization and inhibits $\mathrm{NF}-\kappa \mathrm{B}$ signaling. When basal $\mathrm{NF}-\kappa \mathrm{B}$ activity is high, combination treatment of selinexor with proteasome inhibitors leads to synergistic cytotoxic activity in vitro and in vivo. Therefore, combination treatment of selinexor with proteasome inhibitors may be beneficial in patients resistant to either single agent. This work demonstrates the effect of XPO1 inhibition on the NF- $\mathrm{KB}$ pathway and provides a compelling rationale for combining selinexor with proteasome inhibitors as a viable option for clinical therapy.

\section{MATERIALS AND METHODS}

\section{Cell culture and reagents}

U-2 OS cells (\#HTB-96) and HT-1080 cells (\#CCL121) were purchased from ATCC and cultured in McCoy's 5A (Gibco\#12330-031) and EMEM (Corning\#10-010$\mathrm{CV})$ media, respectively. Media was supplemented with $10 \%$ heat-inactivated fetal bovine serum (Corning\#35011-CV), 100 units $/ \mathrm{mL}$ penicillin, $100 \mu \mathrm{g} / \mathrm{mL}$

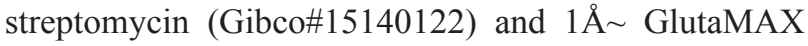
(Gibco\#35050-061). 


\section{Antibodies and reagents}

Antibodies to Phospho IкB- $\alpha$ (9246), Phospho NF-

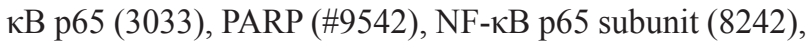
Foxo3A (2497) were purchased from Cell Signaling; p21 (ab16767), IкB- $\alpha$ (ab32518), IKK $\gamma$ (ab63255), GAPDH (ab8245) were purchased from Abcam, and p53 (sc-126), XPO1 (sc-5595), $\beta$-actin (sc-81178) and Lamin B (sc6216) were purchased from Santa Cruz Biotechnology. Secondary antibodies were purchased from LI-COR and Invitrogen (\#A11008). siRNA against IкB- $\alpha$ (s9512) and BLOCK-iT Alexa Fluor Fluorescent Control (\#14750-100) were purchased from Life Technologies.

\section{Compounds}

Selinexor was obtained from Karyopharm Therapeutics. Bortezomib (\#S1013) and carfilzomib (\#S2853) were purchased from Selleckchem. K252a (\#K1639) was purchased from Sigma Aldrich.

\section{IкB- $\alpha$ silencing and cytotoxicity assays}

U-2 OS cell lines were transfected with $40 \mathrm{nM}$ of I $\kappa$ B- $\alpha$ siRNA or $40 \mathrm{nM}$ BLOCK-iT using Lipofectamine RNAiMAX reagent (\#13778100, Life Technologies) following the manufacturer's instructions. The transfection was performed using antibiotic free McCoy's 5A media. Twenty-four hours post-transfection, U-2 OS cells were treated with different concentrations of selinexor in triplicate for the following 72 hours. Cell viability was analyzed using CellTiter-Fluor Cell Viability Assay (\#G6080, Promega) and the half maximal inhibitory concentration $\left(\mathrm{IC}_{50}\right)$ of selinexor for each condition was calculated using XLfit. Western blotting was performed to evaluate the protein expression of IкB- $\alpha$ in the transfected cells.

\section{$\mathrm{NF}-\kappa \mathrm{B}$ transcriptional activity assay}

Cells were seeded in either 6- or 12-well plates and were given overnight to adhere. Cells were pre-treated with serial dilutions of selinexor and/or bortezomib for 2 hours and then exposed to $20 \mathrm{ng} / \mathrm{ml}$ $\mathrm{TNF} \alpha$ (Peprotech) for $4 \mathrm{hrs}$ in serum free media. After treatment, the cells were washed with PBS (Invitrogen), and lysed with RIPA buffer (Themo Scientific). The transcription activity of NF- $\mathrm{\kappa B}$ in the cell lysates was measured by Chemiluminescent Transcription Factor Assay kit (Thermo Scientific Catalog\# 89859) according to the manufacturer's instructions. Briefly, $1.5 \mathrm{mg} / \mathrm{ml}$ of RIPA lysed whole cell extract from each treatment were incubated in a 96-well plate bound with NF- $\mathrm{BB}$ biotinylated-consensus sequence. The active NF- $\kappa B$ transcription factor bound to the consensus sequence is incubated with NF- $\mathrm{kB}$ p65 primary antibody and then with a secondary HRP-conjugated antibody. A chemiluminescent substrate is added to the wells and the resulting signal is detected using a luminometer.

\section{Western blotting}

Cells were seeded in 6-well plates at a density of $0.5 \times 10^{6}$ cells/well. Post treatment, the cells were washed with 1X PBS and then lysed with RIPA buffer (\#89901, Thermo Scientific) supplemented with protease inhibitors (\# 05892791001, Roche) and phosphatase inhibitors (\# 04906837001, Roche). The protein level of each sample was quantified and normalized using BCA assay (\#23225, Thermo Scientific). $20 \mu \mathrm{g}$ of each sample were run in $4-12 \%$ Bis-Tris Gel (Life Technologies) and later transferred to nitrocellulose membrane using iBlot Gel Transfer Kit (Life Technologies). The membranes were blocked using LI-COR blocking buffer (\#927-40000, LI$\mathrm{COR}$ ), probed with the indicated antibodies and analyzed using Licor Odyssey.

\section{Cell proliferation assay}

SINE compound resistant HT-1080 (HT-1080-R) and ASPS-KY cells were seeded in 96-well plates at a density of 3,000 cells per well and allowed to adhere overnight. Cells were then incubated at $37^{\circ} \mathrm{C}$ in a $5 \%$ humidified $\mathrm{CO}_{2}$ incubator for 72 hours with various concentrations of selinexor with or without bortezomib or carfilzomib at different concentrations. Cell viability was determined using CellTiter-Fluor Viability Assay (\# G6082; Promega) as instructed by the manufacturer. $\mathrm{IC}_{50}$ was calculated using XLfit software.

\section{Subcellular fractionation}

For nuclear/cytoplasmic protein fractionation, cells were treated with selinexor, bortezomib or both. Cells were trypsinized, washed with PBS and cellular fractionation was carried out using the NE-PER nuclear and cytoplasmic extraction kit (Thermo Scientific\#78833) according to the manufacturer's instructions. Fractionation efficiency was evaluated by protein expression of subcellular marker proteins; GAPDH (cytoplasmic) and Lamin B (nuclear).

\section{Immunofluorescence}

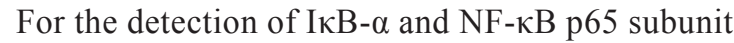
localization, cells were treated according to the study design and washed with PBS. Cells were fixed with $100 \%$ ice-cold methanol $(\mathrm{MeOH})$ and permeabilized/ blocked with $0.1 \%$ Tween $20,0.3 \mathrm{M}$ glycine, and $1 \%$ BSA in PBS. The rabbit secondary antibody, Alexa Fluor 488 (Invitrogen, A11008) was used for all the staining, while nuclei were stained with DAPI (Invitrogen). Protein localization was visualized with 
a Nikon Eclipse Ti inverted fluorescence microscope (Nikon) and monochrome camera (ANDOR) at 20X magnification.

\section{IKK $\beta$ kinase assay}

Activity of IKK $\beta$ was quantified by IKK $\beta$ kinase assay/inhibitor screening kit (MBL \#CY-1178) using recombinant IKB- $\alpha$ polypeptide, containing 2 serine residues, which are substrates of IKK $\beta$. Phosphorylation of IKB- $\alpha$ by purified recombinant IKK $\beta$ was measured the presence of selinexor or K252A using a horseradish peroxidase conjugate of an anti- phospho IKB- $\alpha$ s32 specific antibody, which then catalyzes the conversion of the chromogenic substrate tetra-methylbenzidine from a colorless solution to a blue solution. The absorbance for each sample was measured using a spectrophotometric plate reader at dual wavelengths of $450 / 540 \mathrm{~nm}$.

\section{Xenograft study}

The efficacy of selinexor as a single agent or in combination with bortezomib was evaluated in vivo. 60 female ICR-SCID mice (3-4 weeks old) were purchased from Taconic farms (Germantown, NY). All IACUC approved animal experiments were carried out at Wayne State University facility. To generate xenograft tumors initially, 1 X10 $0^{6}$ HT-1080-R cells were injected subcutaneously in the flank of 3 naïve mice. Four weeks post initiation, palpable tumors were formed at which mice were euthanized, and tumors harvested and $50 \mathrm{mg}$ pieces were re-implanted unilaterally into the flank of experimental groups. Two weeks post transplantation, tumor-bearing mice were randomized into 4 different cohorts each with 10 animals; control, bortezomib at $1 \mathrm{mg} /$ $\mathrm{kg}$ iv; selinexor $15 \mathrm{mg} / \mathrm{kg}$ orally and the combination of bortezomib at $1 \mathrm{mg} / \mathrm{kg}+$ selinexor at $15 \mathrm{mg} / \mathrm{kg}$. All single or combination therapy was administered Monday and Thursday for 2 weeks.

\section{CONFLICTS OF INTEREST}

TK, CA, TJU, BK, CD, WS, ML, MK, SS and YL are full time Karyopharm, Inc. employees. AA, RMM, IM, ASA are from Wayne State University School of Medicine and they have no conflicts of interest to disclose.

\section{REFERENCES}

1. Senapedis WT, Baloglu E, Landesman Y. Clinical translation of nuclear export inhibitors in cancer. Semin Cancer Biol. 2014; 27:74-86.

2. Chook YM, Süel KE. Nuclear import by karyopherin- $\beta$ s: recognition and inhibition. Biochim Biophys Acta. 2011; 1813:1593-1606.
3. Fornerod M, Ohno M, Yoshida M, Mattaj IW. CRM1 is an export receptor for leucine-rich nuclear export signals. Cell. 1997; 90:1051-1060.

4. Turner JG, Sullivan DM. CRM1-mediated nuclear export of proteins and drug resistance in cancer. Curr Med Chem. 2008; 15:2648-2655.

5. Xu D, Farmer A, Collett G, Grishin NV, Chook YM. Sequence and structural analyses of nuclear export signals in the NESdb database. Mol Biol Cell. 2012; 23:3677-3693.

6. Culjkovic B, Topisirovic I, Skrabanek L, Ruiz-Gutierrez M, Borden KL. eIF4E is a central node of an RNA regulon that governs cellular proliferation. J Cell Biol. 2006; 175:415-426.

7. Huang WY, Yue L, Qiu WS, Wang LW, Zhou XH, Sun YJ. Prognostic value of CRM1 in pancreas cancer. Clin Invest Med. 2009; 32:E315.

8. van der Watt PJ, Maske CP, Hendricks DT, Parker MI, Denny L, Govender D, Birrer MJ, Leaner VD. The Karyopherin proteins, Crm1 and Karyopherin beta1, are overexpressed in cervical cancer and are critical for cancer cell survival and proliferation. Int J Cancer. 2009; 124:1829-1840.

9. Yao Y, Dong Y, Lin F, Zhao H, Shen Z, Chen P, Sun YJ, Tang LN, Zheng SE. The expression of CRM1 is associated with prognosis in human osteosarcoma. Oncol Rep. 2009; 21:229-235.

10. Noske A, Weichert W, Niesporek S, Röske A, Buckendahl AC, Koch I, Sehouli J, Dietel M, Denkert C. Expression of the nuclear export protein chromosomal region maintenance/exportin $1 / \mathrm{Xpo} 1$ is a prognostic factor in human ovarian cancer. Cancer. 2008; 112:1733-1743.

11. Nguyen KT, Holloway MP, Altura RA. The CRM1 nuclear export protein in normal development and disease. Int $\mathrm{J}$ Biochem Mol Biol. 2012; 3:137-151.

12. Kalid O, Toledo Warshaviak D, Shechter S, Sherman W, Shacham S. Consensus Induced Fit Docking (cIFD): methodology, validation, and application to the discovery of novel Crm1 inhibitors. J Comput Aided Mol Des. 2012; 26:1217-1228.

13. Neggers JE, Vercruysse T, Jacquemyn M, Vanstreels E, Baloglu E, Shacham S, Crochiere M, Landesman Y, Daelemans D. Identifying drug-target selectivity of smallmolecule CRM1/XPO1 inhibitors by CRISPR/Cas9 genome editing. Chem Biol. 2015; 22:107-116.

14. Abraham SA, Holyoake TL. Redirecting traffic using the XPO1 police. Blood. 2013; 122:2926-2928.

15. Conforti F, Wang Y, Rodriguez JA, Alberobello AT, Zhang YW, Giaccone G. Molecular Pathways: Anticancer Activity by Inhibition of Nucleocytoplasmic Shuttling. Clin Cancer Res. 2015; 21:4508-4513.

16. Mendonca J, Sharma A, Kim HS, Hammers H, Meeker A, De Marzo A, Carducci M, Kauffman M, Shacham S, Kachhap S. Selective inhibitors of nuclear export (SINE) as novel therapeutics for prostate cancer. Oncotarget. 2014; 5:6102-6112. doi: 10.18632/oncotarget.2174. 
17. Tai YT, Landesman Y, Acharya C, Calle Y, Zhong MY, Cea M, Tannenbaum D, Cagnetta A, Reagan M, Munshi AA, Senapedis W, Saint-Martin JR, Kashyap T, et al. CRM1 inhibition induces tumor cell cytotoxicity and impairs osteoclastogenesis in multiple myeloma: molecular mechanisms and therapeutic implications. Leukemia. 2014; 28:155-165.

18. Inoue $H$, Kauffman $M$, Shacham S, Landesman Y, Yang J, Evans CP, Weiss RH. CRM1 blockade by selective inhibitors of nuclear export attenuates kidney cancer growth. J Urol. 2013; 189:2317-2326.

19. Turner JG, Dawson J, Emmons MF, Cubitt CL, Kauffman M, Shacham S, Hazlehurst LA, Sullivan DM. CRM1 Inhibition Sensitizes Drug Resistant Human Myeloma Cells to Topoisomerase II and Proteasome Inhibitors both In Vitro and Ex Vivo. J Cancer. 2013; 4:614-625.

20. Nakayama R, Zhang YX, Czaplinski JT, Anatone AJ, Sicinska ET, Fletcher JA, Demetri GD, Wagner AJ. Preclinical activity of selinexor, an inhibitor of XPO1, in sarcoma. Oncotarget. 2016; 7:16581-16592. doi: 10.18632/ oncotarget.7667.

21. Sun H, Lin DC, Cao Q, Guo X, Marijon H, Zhao Z, Gery S, Xu L, Yang H, Pang B, Lee VK, Lim HJ, Doan N, et al. CRM1 Inhibition Promotes Cytotoxicity in Ewing Sarcoma Cells by Repressing EWS-FLI1-Dependent IGF-1 Signaling. Cancer Res. 2016; 76:2687-2697.

22. Das A, Wei G, Parikh K, Liu D. Selective inhibitors of nuclear export (SINE) in hematological malignancies. Exp Hematol Oncol. 2015; 4:7.

23. Gravina GL, Tortoreto M, Mancini A, Addis A, Di Cesare E, Lenzi A, Landesman Y, McCauley D, Kauffman M, Shacham S, Zaffaroni N, Festuccia C. XPO1/CRM1selective inhibitors of nuclear export (SINE) reduce tumor spreading and improve overall survival in preclinical models of prostate cancer (PCa). J Hematol Oncol. 2014; 7:46.

24. Green AL, Ramkissoon SH, McCauley D, Jones K, Perry JA, Hsu JH, Ramkissoon LA, Maire CL, Hubbell-Engler B, Knoff DS, Shacham S, Ligon KL, Kung AL. Preclinical antitumor efficacy of selective exportin 1 inhibitors in glioblastoma. Neuro Oncol. 2015; 17:697-707.

25. Gerecitano J. SINE (selective inhibitor of nuclear export)-translational science in a new class of anti-cancer agents. $\mathrm{J}$ Hematol Oncol. 2014; 7:67.

26. Parikh K, Cang S, Sekhri A, Liu D. Selective inhibitors of nuclear export (SINE)--a novel class of anti-cancer agents. J Hematol Oncol. 2014; 7:78.

27. Wettersten HI, Landesman Y, Friedlander S, Shacham S, Kauffman M, Weiss RH. Specific inhibition of the nuclear exporter exportin-1 attenuates kidney cancer growth. PLoS One. 2014; 9:e113867.

28. Azmi AS, Aboukameel A, Bao B, Sarkar FH, Philip PA, Kauffman M, Shacham S, Mohammad RM. Selective inhibitors of nuclear export block pancreatic cancer cell proliferation and reduce tumor growth in mice. Gastroenterology. 2013; 144:447-456.
29. Lapalombella R, Sun Q, Williams K, Tangeman L, Jha S, Zhong Y, Goettl V, Mahoney E, Berglund C, Gupta S, Farmer A, Mani R, Johnson AJ, et al. Selective inhibitors of nuclear export show that CRM1/XPO1 is a target in chronic lymphocytic leukemia. Blood. 2012; 120:4621-4634.

30. Abdul Razak AR, Mau-Soerensen M, Gabrail NY, Gerecitano JF, Shields AF, Unger TJ, Saint-Martin JR, Carlson R, Landesman Y, McCauley D, Rashal T, Lassen U, Kim R, et al. First-in-Class, First-in-Human Phase I Study of Selinexor, a Selective Inhibitor of Nuclear Export, in Patients With Advanced Solid Tumors. J Clin Oncol. 2016.

31. Gounder MM, Zer A, Tap WD, Salah S, Dickson MA, Gupta AA, Keohan ML, Loong HH, D'Angelo SP, Baker S, Condy M, Nyquist-Schultz K, Tanner L, et al. Phase IB Study of Selinexor, a First-in-Class Inhibitor of Nuclear Export, in Patients With Advanced Refractory Bone or Soft Tissue Sarcoma. J Clin Oncol. 2016.

32. Alexander TB, Lacayo NJ, Choi JK, Ribeiro RC, Pui CH, Rubnitz JE. Phase I Study of Selinexor, a Selective Inhibitor of Nuclear Export, in Combination With Fludarabine and Cytarabine, in Pediatric Relapsed or Refractory Acute Leukemia. J Clin Oncol. 2016.

33. Johnson C, Antwerp DA, Hope TJ. An N-terminal nuclear export signal is required for the nucleocytoplasmic shuttling of IкB $\alpha$. EMBO J. 1999; 18:6682-6693.

34. Krappmann D, Scheidereit C. Regulation of NF-kappa B activity by I kappa B alpha and I kappa B beta stability. Immunobiology. 1997; 198:3-13.

35. Scott ML, Fujita T, Liou HC, Nolan GP, Baltimore D. The p65 subunit of NF-kappa B regulates I kappa B by two distinct mechanisms. Genes Dev. 1993; 7:1266-1276.

36. Viatour P, Merville MP, Bours V, Chariot A. Phosphorylation of NF-kappaB and IkappaB proteins: implications in cancer and inflammation. Trends Biochem Sci. 2005; 30:43-52.

37. Ding GJ, Fischer PA, Boltz RC, Schmidt JA, Colaianne JJ, Gough A, Rubin RA, Miller DK. Characterization and quantitation of NF-kappaB nuclear translocation induced by interleukin-1 and tumor necrosis factor-alpha. Development and use of a high capacity fluorescence cytometric system. J Biol Chem. 1998; 273:28897-28905.

38. Demchenko YN, Glebov OK, Zingone A, Keats JJ, Bergsagel PL, Kuehl WM. Classical and/or alternative NF-kappaB pathway activation in multiple myeloma. Blood. 2010; 115:3541-3552.

39. Traenckner EB, Pahl HL, Henkel T, Schmidt KN, Wilk S, Baeuerle PA. Phosphorylation of human I kappa B-alpha on serines 32 and 36 controls I kappa B-alpha proteolysis and NF-kappa B activation in response to diverse stimuli. EMBO J. 1995; 14:2876-2883.

40. Michalaki V, Syrigos K, Charles P, Waxman J. Serum levels of IL-6 and TNF-alpha correlate with clinicopathological features and patient survival in patients with prostate cancer. Br J Cancer. 2004; 90:2312-2316.

41. Karayiannakis AJ, Syrigos KN, Polychronidis A, Pitiakoudis M, Bounovas A, Simopoulos K. Serum levels 
of tumor necrosis factor-alpha and nutritional status in pancreatic cancer patients. Anticancer Res. 2001; 21:1355-1358.

42. Forones NM, Mandowsky SV, Lourenço LG. Serum levels of interleukin-2 and tumor necrosis factoralpha correlate to tumor progression in gastric cancer. Hepatogastroenterology. 2001; 48:1199-1201.

43. Berberoglu U, Yildirim E, Celen O. Serum levels of tumor necrosis factor alpha correlate with response to neoadjuvant chemotherapy in locally advanced breast cancer. Int J Biol Markers. 2004; 19:130-134.

44. Mercurio F, Zhu H, Murray BW, Shevchenko A, Bennett BL, Li J, Young DB, Barbosa M, Mann M, Manning A, Rao A. IKK-1 and IKK-2: cytokine-activated IkappaB kinases essential for NF-kappaB activation. Science. 1997; 278:860-866.

45. Régnier CH, Song HY, Gao X, Goeddel DV, Cao Z, Rothe M. Identification and characterization of an IkappaB kinase. Cell. 1997; 90:373-383.

46. Sakurai H, Chiba H, Miyoshi H, Sugita T, Toriumi W. IkappaB kinases phosphorylate NF-kappaB p65 subunit on serine 536 in the transactivation domain. J Biol Chem. 1999; 274:30353-30356.

47. Karin M. How NF-kappaB is activated: the role of the IkappaB kinase (IKK) complex. Oncogene. 1999; 18:6867-6874.

48. Crochiere M, Senapedis W, Kashyap T, Rashal T, McCauley D, Kauffman M, Shacham S, Landesman Y. The Selective Inhibitor of Nuclear Export Compound, Selinexor, Inhibits NF- $\kappa \mathrm{B}$ and Induces Anti-Non-Small Cell Lung Cancer Activity Regardless of p53 Status. International Journal of Cancer Research and Molecular Mechanisms. 2016; 2.

49. Kashyap T, Crochiere M, Kalid O, Shechter S, Klebanov B, Senapedis W, Saint-Martin JR, Landesman Y. Deciphering mechanisms of drug sensitivity and resistance to Selective Inhibitor of Nuclear Export (SINE) compounds. BMC Cancer. 2015; 15:910.
50. Hoshino M, Ogose A, Kawashima H, Izumi T, Hotta T, Hatano H, Morita T, Otsuka H, Umezu H, Yanoma S, Tsukuda M, Endo N. Molecular analyses of cell origin and detection of circulating tumor cells in the peripheral blood in alveolar soft part sarcoma. Cancer Genet Cytogenet. 2009; 190:75-80.

51. Traenckner EB, Wilk S, Baeuerle PA. A proteasome inhibitor prevents activation of NF-kappa B and stabilizes a newly phosphorylated form of I kappa B-alpha that is still bound to NF-kappa B. EMBO J. 1994; 13:5433-5441.

52. Palombella VJ, Rando OJ, Goldberg AL, Maniatis T. The ubiquitin-proteasome pathway is required for processing the NF-kappa B1 precursor protein and the activation of NF-kappa B. Cell. 1994; 78:773-785.

53. Sakakibara K, Saito N, Sato T, Suzuki A, Hasegawa Y, Friedman JM, Kufe DW, Vonhoff DD, Iwami T, Kawabe T. CBS9106 is a novel reversible oral CRM1 inhibitor with CRM1 degrading activity. Blood. 2011; 118:3922-3931.

54. Sun Q, Carrasco YP, Hu Y, Guo X, Mirzaei H, Macmillan J, Chook YM. Nuclear export inhibition through covalent conjugation and hydrolysis of Leptomycin B by CRM1. Proc Natl Acad Sci U S A. 2013; 110:1303-1308.

55. Mahipal A, Malafa M. Importins and exportins as therapeutic targets in cancer. Pharmacol Ther. 2016.

56. Azam M, Seeliger MA, Gray NS, Kuriyan J, Daley GQ. Activation of tyrosine kinases by mutation of the gatekeeper threonine. Nat Struct Mol Biol. 2008; 15:1109-1118.

57. Rodriguez MS, Thompson J, Hay RT, Dargemont C. Nuclear retention of IkappaBalpha protects it from signal-induced degradation and inhibits nuclear factor kappaB transcriptional activation. J Biol Chem. 1999; 274:9108-9115.

58. Hay RT, Vuillard L, Desterro JM, Rodriguez MS. Control of NF-kappa B transcriptional activation by signal induced proteolysis of I kappa B alpha. Philos Trans R Soc Lond B Biol Sci. 1999; 354:1601-1609. 